\title{
A MESTERSÉGES INTELLIGENCIA LEHETSÉGES HATÁSA(I) A „MUNKA VILÁGÁRA”
}

\author{
Nagy Valéria - Hajdu Vanda
}

\begin{abstract}
Absztrakt: A munka mindig is életünk része volt. Fizikai és szellemi tevékenységünk révén nyílik lehetőség társadalmi fejlődésre és a gazdaság átrendezésére (adott esetben gazdasági növekedésre). Az életen át tartó tanulás ( $L L L=$ lifelong learning) pedig - akár formális, akár informális vagy éppen non-formális - ahhoz segíti hozzá az emberiséget, hogy olyan teljesítményképes tudásra tegyen szert, amely állandó cselekvésre sarkallja. Mindemellett fontos megjegyezni, hogy a 'munka' szláv jövevényszó (valószínüleg indoeurópai eredetü) és kín, gyötrelem, vesződség, szenvedés, erőlködés, erőfeszítés jelentésekkel bír. Az ipari forradalmakat megtestesítő folyamatos technikai, technológiai innovációk révén már szükségszerüen megjelent szempontként a monoton emberi munka, illetve az emberre ártalmas munkavégzés kiváltása gépekkel. Napjainkban pedig a munkavállalói élménynek is egyre inkább elötérbe kell kerülnie. A mesterséges intelligenciában rejlő lehetőségek között ez utóbbi is ott húzódik, hiszen e technológia alkalmazásával olyan munkakörök jöhetnek létre, ahol az emberi gondolkodás, a kreativitás, az egyediség a legfontosabb készségek, képességek. Közleményünk e témában enged elmélyedni egy kicsit. Az utóbbi néhány év (tudományos) írásművei, szakpolitikai és statisztikai dokumentumai, valamint egyéb ismeretterjesztő müvek alapján reflektív gondolatok formájában felvillantja a mesterséges intelligenciának a munka világában érzékelhető lehetséges hatásait, vagyis a benne rejlő lehetőségeket és kihívásokat. Ezt sejteti a közlemény címe is, lévén hogy előnyökről és hátrányokról még nem beszélhetünk, hiszen nem kiforrott technológiáról van szó, hanem a bevezetési fázisában lévőről.
\end{abstract}

Abstract: Work has always been a part of our lives. Through our physical and mental activity, there is an opportunity for social development and economic restructuring (possibly economic growth). And lifelong learning (LLL), whether formal, informal or non-formal, helps humanity to acquire powerful knowledge that encourages constant action. However, it is important to note that the word 'munka' is a Slavic newcomer word (probably of Indo-European origin) with meanings of torment, fatigue, suffering, exertion, effort. Through continuous technical and technological innovations, which represent industrial revolutions, it was necessary to replace monotonous human work and harmful work for humans. Nowadays, the employee experience must come to the fore. Among the possibilities inherent in artificial intelligence, there is also this, as with the application of this technology, jobs can create where human thinking, creativity and uniqueness are the most important skills and abilities. Our paper on this topic allows us to delve a little more. Based on the (scientific) writings, policy and statistical documents, and other dissemination papers have been published in the last few years, these flash in the form of reflective thoughts the possible effects of artificial intelligence in the world of work, in fact the opportunities and challenges. This is also suggested by the title of the paper, as we cannot talk about advantages and disadvantages yet, as it is not a mature technology, but one that is in the implementation phase.

Kulcsszavak: élőmunka, mesterséges intelligencia, Ipar 5.0, munkavállalói élmény

Keywords: human work, artificial intelligence, Industry 5.0, employee experience

\section{Bevezetés}

Tényként kezelendő, hogy minden új technológia (összetett) változásokat indukál. A múltbeli tapasztalatokra és a jelenbeli kezdeményezésekre alapozottan körvonalazódik, hogy az automatizáció és a mesterséges intelligencia, mint a jelen digitalizációs törekvése egyaránt hatással van és lesz az iparra (az ipari szereplőkre), a közigazgatásra, az oktatásra, az egészségügyre stb. E területeken többnyire az 
előnyök kerülnek a fókuszba, míg a társadalomra gyakorolt hatás vonatkozásában számtalan kockázattal (Nicola et al., 2018), kihívással is szembe kell néznünk. Egyik ilyen kihívás (lesz) a munkaerőpiacra gyakorolt hatás, ezáltal vélhetően át is alakítja az emberek életét.

Tanulmányunk mottójának Bugát Pál (1793-1865) szemészorvos, nyelvész szavait választottuk: „Minden emberi gondolat cselekedetté valósulni vágyakodik.” Vagyis mindenkor szem előtt kell tartanunk, hogy annak a nagyszerü emberi képességnek - amit úgy hívunk, hogy gondolkodás - a birtokában vagyunk képesek olyan szellemi „termékek” létrehozására, amelyek sok-sok ember életét megkönnyít(het)ik, illetve mindennapjait élhetővé tehetik, élhetővé teszik. És lehetséges ez, mert az intelligencia harmadik változata az emberi intelligencia: természetes és mesterséges egyszerre (Ropolyi, 2020). Tehát az emberek - mint tudattal bíró pszichikai „rendszerek” - és az őket érintő változások relációjában felsejlik a kérdés, hogy a munkavállalói élmény vajon milyen szerepet kap vagy egyáltalán megjelenik-e szempontként? E kérdés megválaszolásához a hivatkozott irodalmak felhasználásával reflektív gondolatokként megjelennek a mesterséges intelligenciában rejlő lehetőségek és kihívások a munka világára vonatkoztatva.

A közlemény egészét tekintve érdemes az egyes részekre külön-külön is utalni. Az Anyag és módszert követően egy hosszabb helyzetértékelés - mint egy prolegomena - érzékelteti azt a változást, amely már ott áll a munka világának kapujában. A mesterséges intelligencia megjelenésével, térhódításával nemcsak lehetségessé, de elkerülhetetlenné is válik a munkaerőpiaci innováció, mint „az emberi elme kreatív tevékenysége" (Brynteson, 2012), illetve az új megoldásokra való törekvés. Korunk felgyorsult világa, ebböl következően a feszes életrendünk megváltoztatja a munkához való viszonyunkat, ugyanakkor kiszélesíti lehetőségeinket. Azonban esszenciális erővel bír a folyamatban az új munkavállalói környezet társadalmi hatásmechanizmusának elörejelzése is. Itt megjegyzendő, hogy a nemzetközi példákat ,jelentős" késéssel követjük.

A társadalmi hatások várhatóan olyan mértéküek lesznek, amelyek kikényszerítik a harmadik évezred munkavállalójának szemléletváltozását is és a munkaerőpiaci gyakorlatok megváltozását is. Továbbá várhatóan átalakulnak a munkavállalói készségek is.

\section{Anyag és módszer}

A közlemény célkitüzésének megvalósítása néhány releváns hazai és nemzetközi kutatás (rész)eredményein, valamint szakpolitikai iránymutatásokon és statisztikai adatokon alapul. Ezeknek a (rész)eredményeknek, iránymutatásoknak és adatoknak a szintetizáló összegzése és értékelése történik meg a közlemény fő fejezeteiben. A kiválasztott írásmüvek között megtalálhatók a mesterséges intelligenciában, mint úttörő technológiában rejlő lehetőségeket, kihívásokat sejtető, illetőleg a gazdaságitársadalmi vonatkozású elemzéseket felvonultató írásmüvek is, amelyek fókuszában a munka áll. Ugyanis a mesterséges intelligencia indukálta körülményekhez illeszkedő optimális feltételrendszer - etikai, pszichológiai és jogi keret- és peremfeltételek - kialakítása ugyanis a müszaki, a gazdasági, illetve a 
társadalomtudományi, jogi területeken tevékenykedő szakemberek egymás szemlélete iránt nyitott együttmüködésében realizálható. A Rendszerezett Tételes Szakirodalmi Áttekintés (SQLR=Systematic Quantitative Literature Review) módszert alkalmaztuk a releváns irodalmak, információk összegyüjtéséhez. Különösen alkalmas a módszer a transzdiszciplináris és interdiszciplináris vizsgálódásra, ahol a módszertani megközelítések igen sokfélék (Pickering-Byrne, 2014). Jellegét tekintve inkább interszubjektív, hiszen a jelenlegi állapot megismerése mellett lehetővé válik a hiányosságok azonosítása is, míg a „hagyományos" narratív stílus hátrányaként említhető talán a potenciális elfogultság. Tehát a reflektív szemlélettel áthatott bemutatás révén a kiválasztott és feldolgozott írásművek azon fontosabb gondolatai olvashatók a következő két fejezetben, amelyek alapján munkavállalóként fel lehet és fel kell készülnünk a változásokra.

\section{Helyzetértékelés}

Mielőtt tehát az előrejelzés szándékával a várható hatásokat (lehetőségeket és kihívásokat) bemutatjuk és elemezzük, helyzetértékelés végzendő a jelenben. Jelen viszont nem létezik múlt nélkül. A múltbeli események bemutatásához segítségül kell hívni a történelmet, leszükítve az ipari forradalmak korszakaira.

Az alábbi ábra (1. ábra) a teljesség igénye nélkül szemlélteti a (múlt és) jelen azon fontosabb történéseit, amelyeknek közvetlen hatása jelentkezett az emberi munkavégzés vonatkozásában, ugyanakkor előre vetül a jövő, a közeljövő is.

\section{1. ábra: Jelen és (közel)jövő}

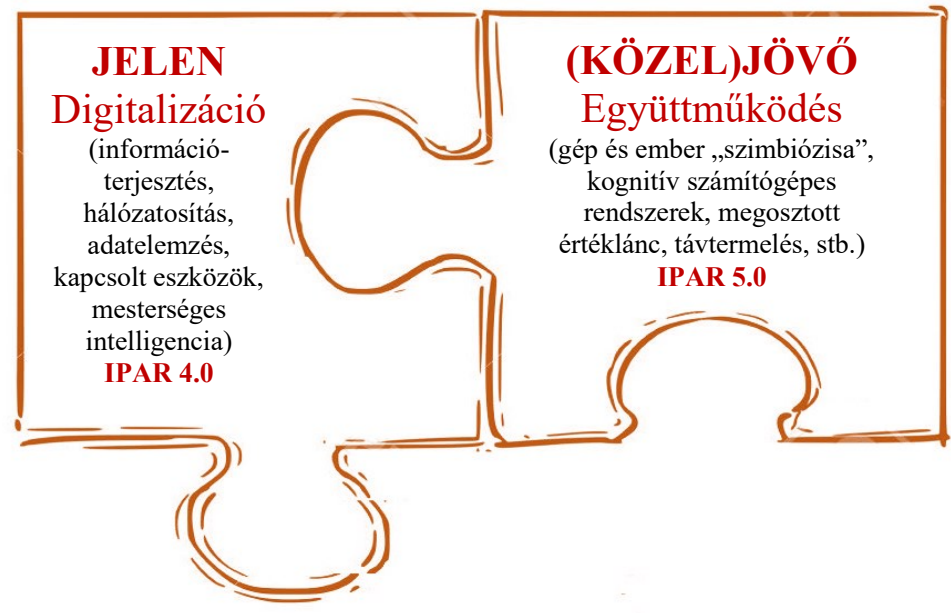

Forrás: A szerzők szerkesztése

A jelent meghatározó Ipar 4.0 irányzat (iránymutatás) elsősorban olyan területekre fókuszál( $\mathrm{t}$ ), ahol a monoton emberi munkát és/vagy az emberre ártalmas munkavégzést, továbbá az emberi pontosságot meghaladó minőségi követelmények szerinti munkavégzést kell(ett) (részben) kiváltani. Ezek hátterében húzódnak a környezeti terhelést csökkentő törekvések (pazarlás megszüntetése, a hulladék 
keletkezésének megelőzése, illetve a hozzáadott értékkel rendelkező újrahasznosítás révén) is, amelyek szintén figyelembe veendők.

Példának okáért álljon itt néhány konkrét terület:

- precíziós, robotizált gépgyártás;

- $\quad$ anyagszelektáló rendszerek;

- nanotechnológia;

- fotonika;

- bionika;

- lézertechnológia;

- diagnosztikai képalkotás;

- mütéti beavatkozások támogatása stb.

Ugyanakkor az egyik legérzékenyebb társadalmi hatás (pl. a munkahelyek kérdése) csak ,jósolható” és sajnos a jog is csupán követi a technikai/technológiai fejlődést, de elő nem mozdítja azt. Tulajdonképpen a robotika elvitathatatlan szerepe és az emberi faktor újraértékelése kelti életre az Ipar 5.0 filozófiáját, amikor a gép és ember úgy tud együtt dolgozni, hogy hatékonyabb lesz a termelés, szolgáltatás (a kevesebb időráfordítás és a kevesebb hiba révén). És ez már nem a távoli jövő.

Itt azonban fontos megemlíteni a hadiipart (Négyesi, 2019; Erdész, 2020) is, amely területen már a kezdetektől szimbiózis mutatkozott a mesterséges intelligencia és az emberi munkavégzés együttesében.

De visszatérve a társadalmi hatásokra, közöttük a munkaerőpiaci hatásokra: az átmeneti időszakban ideális esetben az lenne elfogadható, ha a törekvések az emberi intelligencia és a kognitív számítástechnika előnyeit ötvözve jelennének meg a hatékonyság érdekében (figyelembe véve a társadalmi hatásokat is). Ugyanis azt mindannyian érzékeljük, hogy a társadalmi fejlödés messze elmaradt/lemaradt a müszaki/technikai/technológiai fejlödéstől. Fontos momentum az is, hogy a robot és az ember hatékony együttmüködése eredményezhet innováció-kultúrát.

Említést érdemel továbbá a Collingridge-dilemma is, amely éppen arra hívja fel a figyelmet, hogy egy adott technológia bevezetése elött, illetve beágyazódása során a technológia hatásainak átfogó elemzése szükséges annak érdekében, hogy minél több információ álljon rendelkezésre a bevezetéshez, elterjesztéshez. A munkaerőpiacot érintő változások okán tehát a befogadó társadalom kialakítása elengedhetetlen.

A mesterséges intelligencia „olyan világot teremt, amelyben folyamatos alkalmazkodásra, az újdonságok követésére és tanulásra lesz szükség a teljes életünk során”. Hiszen ,a mesterséges intelligencia az emberi intelligencia valamely részének leképezésére alkalmas szoftver, amely képes támogatni vagy autonóm módon ellátni észlelési, értelmezési, döntési vagy cselekvési folyamatokat. Egy technológia, amely speciális képességekkel rendelkezik, mégis kiemelt figyelem kíséri” mind gazdasági, mind társadalmi szinten (MIS 2020).

Talán a mesterséges intelligencián alapuló alkalmazások használatához többre lesz szükség a kreatív egyéneknél és nem feltétlenül lesz elegendő a nyitottság az új iránt vagy éppen a rugalmasság, illetve a nonkonformizmus, hanem sokkal inkább erősen fejlett kritikus gondolkodásra lesz szükség. 
A ,permanens képzés és tanulás” szükségessége (Maróti, 2014) okán tehát a szakképzésnek is és a felsőoktatásnak is fel/elő kell készítenie a fiatalokat az életre és a munkára az új, még csak kialakuló viszonyok között. Minden kor oktatási rendszere e feladattal találja szemben magát (Suchodolski, 1964), amely az utóbbi években egyre inkább előtérbe kerül. A gyorsan változó világ miatt mellőzhetetlen az életen át tartó tanulás, vagyis kombinálódik a tanulás, a munka és a szabadidő (Lai et al., 2013). Viszont kiemelkedőt alkotni motiváció, kitartás és szorgalom büvöletében lehet. De hogy ez lehetséges legyen, ahhoz éppen az a fordulat szükséges, amely jelenleg alakítja mindennapjainkat.

A Világgazdasági Fórum (WEF $=$ World Economic Forum) előrevetíti melyek lesznek a közeljövőben (2025-re) a legfontosabb munkavállalói készségek, képességek (WEF 2020). A jelentés 15 készséget, képességet rangsorol, amelyek közül az első öt helyen a következőket találjuk:

- analitikus gondolkodás és innováció;

- aktív tanulás és tanulási stratégiák;

- komplex problémamegoldás;

- kritikus gondolkodás és elemzés;

- kreativitás, egyediség és kezdeményezőkészség.

A 2. ábra megjelenít néhány gondolatot, ami legelöször megfogalmazódik az egyénben, mint munkavállalóban vagy mint potenciális munkavállalóban a mesterséges intelligenciával kapcsolatosan.

\section{2. ábra: Gondolatok a munkavállalásról a mesterséges intelligencia világában}

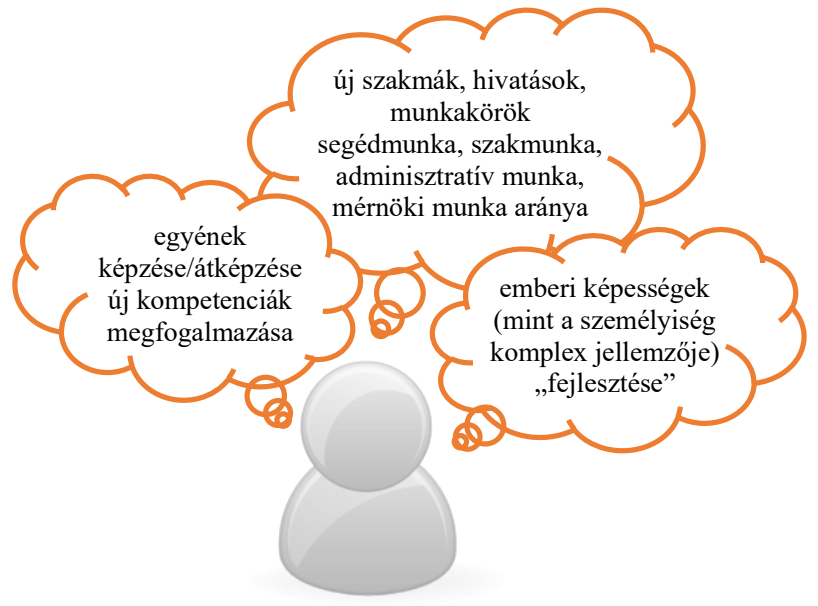

Forrás: A szerzők szerkesztése

Egy magas müszaki kultúrájú társadalom különösképp eredményes tud lenni, ha tudományosan igazolt és kidolgozott iránymutatással is segített, támogatott. Már csak azért is, mert az általában vett automatizáció, digitalizáció és a mesterséges intelligencia szélsőséges esetben bizonyos területeken az élőmunka teljes kiváltásával jár(hat). Erre a változásra azonban fel lehet és fel kell készülni. 
Ennek okán az Európai Bizottság a Fehér Könyv c. dokumentumában az Európai Unió szabályozási kereteit is vizsgálja (öt forgatókönyv), amely a mesterséges intelligencia lehetöségeinek hazai kihasználására is hatással lesz (Fehér Könyv 2020).

Közleményünk további részében az eddig leírtak szellemében arra vállalkozunk, hogy egy rövid kitekintést adjunk a mesterséges intelligencia elterjedésének, elterjesztésének (munkaerőpiaci) hatásairól, különös tekintettel annak (lehetséges) előnyeire, hátrányaira, a lehetőségekre és kihívásokra, a munkaköröket, szakmákat, hivatásokat érintő kérdésekre. Tesszük ezt a monadológia szem elött tartásával, ugyanis a hivatás emberszolgálat (Bagdy, 1991). Kitekintést tesz továbbá a közlemény a lehetőségek és kihívások kontextusában az emberközpontúságra (HTTP1), az embereket szolgáló és életminőséget javító hatásra, a növekvő hozzáadott értékre. A lehetőségek és kihívások előtt álljon itt néhány statisztikai adat „érdekességként":

- Az Oracle és a Future Workplace kutatócég immár második alkalommal végezte el az 'AI at Work' címü közös, globális felmérését, amelynek eredményei szerint az emberek többsége (64\%) jobban bízik a robotokban, mint a feletteseiben (HTTP2).

- A munkavállalók Indiában (60\%) és Kínában (56\%) lelkesednek leginkább a mesterséges intelligencia használatáért, őket követi az Egyesült Arab Emírségek (44\%), Szingapúr (41\%), Brazília (32\%), Ausztrália és ÚjZéland (26\%), Japán (25\%), az Egyesült Államok (22\%), az Egyesült Királyság (20\%) és Franciaország (8\%) (HTTP2).

- A férfiak (32\%) sokkal pozitívabban tekintenek a mesterséges intelligenciára, mint a nők (23\%) (HTTP2).

- A munkavállalók azt szeretnék, ha egyszerűen tudnák használni a mesterséges intelligenciát a munkájuk során, ezért könnyen kezelhető felhasználói felületeket (34\%), gyakorlati képzéseket (30\%) és a viselkedésükre szabott élményeket (30\%) szeretnének (HTTP2).

- A legfőbb okok között, amelyek visszatartják a munkavállalókat a mesterséges intelligencia használatától, a biztonság (31\%) és az adatvédelem (30\%) szerepel (HTTP2).

Érdemes elmélyedni például David et al. (2018) tanulmányában, amely a mesterséges intelligencia elterjedésének, elterjesztésének (munkaerőpiaci) hatásait elemzi.

\section{A mesterséges intelligencia, mint lehetőség a „munka világában”}

A mesterséges intelligencia - mint lehetőség - mellett érvelők elmélete szerint a gépek soha nem fogják tudni helyettesíteni az embert, csupán kiegészíteni, és ilyen módon a gép és az ember együttmüködésének filozófiája meghatározó lesz. Számtalan olyan szakma/hivatás van, ahol ma még nehezen képzelhető el a robotika térnyerése. Többek között ide tartoznak az olyan foglalkozások, ahol fontos a kreativitás és az esztétikai érzék (pl.: rendezvényszervező, belső építész, divattervező, lakberendező, kertépítő), az empátia (pl.: (óvoda)pedagógus, 
pszichológus stb.), a kézügyesség vagy éppen a müvészi hajlamok. Ezek a szakmák/hivatások (talán) kevésbé vannak a teljes „eltünés” veszélyének kitéve (HTTP3), ugyanakkor az ezeket alapjaiban meghatározó emberi tulajdonságok tökéletesítésének egyre nagyobb figyelmet kell szentelni a gépekkel való „versenyben”. Nevezetesen az „Ötletgazdagság és új eszmék iránti nyitottság, a széles spektrumú mintafelismerés és a kommunikáció legkomplexebb formái olyan tudásterületek, ahol az emberek még mindig előnyben vannak a legjobb gépekkel szemben. Sajnos azonban pont ezek a készségek ma nem kapnak elég hangsúlyt az oktatási környezetben." (Makó et al., 2018).

Napjainkban a digitális átállás új gondolkodási módot igényel. A munkaerőpiacnak megfelelö, digitális képességekkel rendelkező fiatalokra van szüksége. Ezért digitális intelligenciára kell szert tennie a sikeres digitális léthez a gyermekeknek (Tóthné, 2020).

A mesterséges intelligencia térhódításának kiemelkedő szerepe lehet az össztársadalmi problémák megoldásában. Egy ilyen terület a környezetvédelem. Például a grönlandi jégtakaró tömegváltozásának vizsgálata során 1992 és 2018 között keletkezett „óriás adathalmaz” (Big Data) elemzése vált lehetővé. Itt megjegyzendő, hogy a közelmúltban még nem állt rendelkezésre olyan technológia, melynek segítségével ekkora adatmennyiség analizálása lehetséges lett volna (Vasali, 2020). A „Big Data” szuperszámítógépekkel történő elemzése számos területen képes olyan információkkal ellátni a gazdaság szereplőit, melyet korábban nem volt mód előállítani. A rövid időn belül kinyerhető, előállítható információhalmaz strukturált és kielemzett formában már önmagában véve is innováció.

Példának okáért megemlíthető, hogy a mezőgazdaságban hatékonyságot és innovációt eredményezhet a mesterséges intelligencia hozzáadott értéke. Ami néhány évtizede még teória szintjén sem volt jelen a gazdálkodók gondolataiban, ma már a jól felszerelt gazdaságok mindennapos valósága: a földmunkákkal járó munkavégzés során talajelemzéseket végző erőgépek és vontatmányaik optimalizálni képesek, hogy mely területen milyen tápanyag-visszapótlásra van szükség (a munkagépekre egy infravörös tartományban müködö talajszonda csatlakoztatható, amely egy 12 V-ról működő kommunikációs egység segítségével Bluetooth kapcsolaton keresztül a vezetöfülkében elhelyezett infokommunikációs eszközön rögzíti a GPS koordinátákhoz tartozó adatokat) (HTTP4).

Ha tehát lehetőségként tekintünk a mesterséges intelligenciára, akkor kidomborítható az embereket szolgáló és életminőséget javító hatás, és érzékelhető a növekvő hozzáadott érték is. Vagyis alapvetésnek kell tekinteni, hogy az emberek jóllétét kell szolgálnia.

A Nemzeti Gazdasági és Társadalmi Tanács 2018. 10. 12-i ülésére készült szakmai háttéranyag az alábbiakra hívja fel a figyelmet a robotizáció és digitalizáció térnyerése kapcsán (Kelemen, 2018):

- olyan minőségi oktatás (a felnőttképzésre is kiterjedően) állami támogatása szükséges, ahol fő cél az újonnan szükséges készségek elsajátítása;

- az új munkavállalási típusok munkajogi szabályainak kidolgozása; 
- alacsony hozzáadott értékü és beszállítói munkára építő gazdasági modell helyett az új, magas hozzáadott értéket teremtő munkahelyek létrehozása;

- közszféra tevékenységeinek modernizálása (adóbevallások, cégbíróság) stb.

Az Európai Bizottság „A mesterséges intelligencia, a dolgok internete és a robotika biztonsági és felelősségi vonatkozásairól” címü jelentésében (COM(2020)64) kitér arra, hogy habár a mesterséges intelligenciával ötvözött automatizálásnak köszönhetően munkahelyek szünnek majd meg, de egyúttal újak is létrejönnek. A robotizáció egyik fő céljának kell lennie a káros munkahelyi környezetnek kitett munkakörök csökkentése és több jó minőségü és tisztességes munkahely létrejötte.

A fentieket összefoglalva tehát a mesterséges intelligencia alkalmazásának számos előnye lehet a gazdaság különböző szereplöi számára az egészségügyi ellátás, az energia, a biztonság, a közlekedés, illetve a közszolgáltatások területén is (HTTP5). A tanulmányozott irodalmak indukálta gondolataink között azonban megjelent az élőmunka teljes kiváltása is.

\section{A mesterséges intelligencia térhódításának kihívásai a „munka világában”}

A mesterséges intelligencia elterjedésének a legtöbbet emlegetett és egyik legjelentősebb rövid távú kockázata, hogy tömeges munkanélküliséghez vezethet. A robotok elterjedésével óhatatlanul felmerül a kérdés, hogy mi lesz a fizikai és szellemi „rutinmunkát” végző széles társadalmi rétegekkel? Hogyan fognak tudni alkalmazkodni az új kihívásokhoz? Itt megjegyzendő azonban, hogy a mesterséges intelligenciához kapcsolódó kockázatokat még nem tanulmányozták kellőképpen. Alapelv azonban - mint ahogyan már említésre került -, hogy az emberek felelös szereplök, tehát a mesterséges intelligenciának az emberek jóllétét kell(ene) szolgálnia. Mivel a piacérett mesterséges intelligencia forradalmi változásokat hoz etikai (erkölcsi) téren, ezért ezeket társadalmi szinten intenzíven meg kell vitatni. Az etikai szempontok közül fontos kiemelni néhányat (COM(2020)64):

- emberközpontú technológia;

- beépített értékek a technológiában;

- mesterséges intelligencia és a robotika autonómiájának korlátozása;

- algoritmusok átláthatósága.

Az könnyen belátható, hogy a munka az emberi önértékelés meghatározó színtere, ahol változásokkal is szembe kell nézni, hiszen munkakörök szünnek meg, de újak is jönnek létre. Felsejlik a technológiai szingularitás és hogy képesek leszünk-e alkalmazkodni. Jelenleg ugyanis a munka strukturálja az emberi életet, ezért beláthatatlan következménnyel járhat a népesség tömeges „munkanélkülivé” válása. Ahogyan az előzőekben már történt rá utalás, a problémát mélyíti, hogy a digitális forradalom mentén kialakuló új szakmák olyan készségeket igényelnek, melyek fejlesztését a jelenlegi oktatási rendszer még nem kellő mértékben támogatja (Bayer, 2020). A nagyarányú munkahelyvesztés ellensúlyozására megoldásként kínálkozhat Andor (2018) szerint az FNA (Feltétel Nélküli Alapjövedelem), hiszen a mesterséges intelligencia etikai keretein túlmutatóan a pszichológiai aggályok is megjelennek, válaszokat kell találni a munka hiányában felszabaduló idő szervezett 
és hasznos eltöltésére. Gondoljunk csak bele hány esetben tapasztalhatjuk a nyugdíjba vonuló egyének hirtelen egészségi és mentális állapotának leromlását. Ebből a szempontból is kiemelkedő fontosságú az életen át tartó tanulás.

Mivel az emberi szükséglet sem állandó, az új termékek kínálata vélhetően megteremti a keresletét. A történelem során egyébként megfigyelhető jelenség a jelentős technológiai fejlődés eredményeként egyes szakmák eltűnése és újak kialakulása, illetve az egy-egy iparági csoportban fellépő munkaerő többlet és hiány kialakulása. A jelenlegi helyzetben a veszély a már említett technológiai szingularitás, tehát a folyamatok idősávban történő „extrém” felgyorsulása. (Itt megjegyzendő, hogy az életen át tartó tanulás lehetőségeket rejt magában.) A folyamat kezdete korábbra datálható, azonban megfigyelhető, hogy a hatékonyság javulásával nem nöttek a bérek és a munkaidő sem csökkent. Ellenben bővül az alacsony jövedelemmel bírók köre. A szociológusok egy új társadalmi osztály kialakulását vetítik elöre. Kérdéses, hogy növekedni fog-e a gépek és robotika térhódításával az emberiség szabadságfoka.

Az alábbi diagram (3. ábra) az ember és a gépek közötti munkamegosztás várható alakulását szemlélteti 2018 és 2025 között. 2025-re megfordul(hat)nak az arányok, azonban ez tőlünk (is) függ.

\section{3. ábra: Az ember és a gépek közötti munkamegosztás várható alakulása 2018-2025 [\%]}

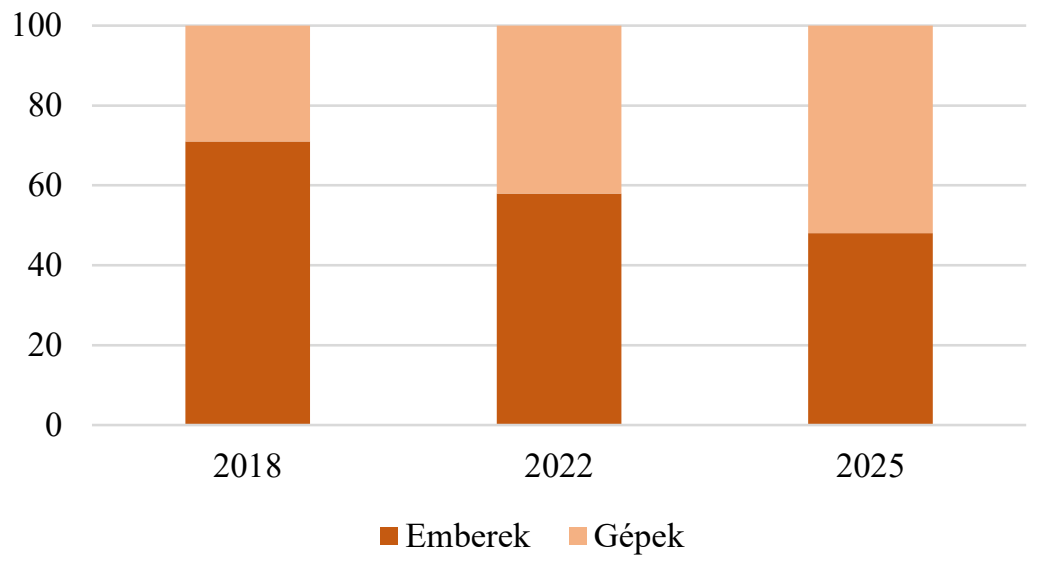

Forrás: HTTP6 (2018)

Rajtunk áll tehát, hogy a „(szuper)számítógépes rendszer” az ember eszköze marad-e, vagy éppen az emberek lesznek a rendszer függelékei; illetve sikerül-e a mesterséges intelligenciát alárendelni az emberiség céljainak.

A hosszabb távú hipotetikus kockázatok között szerepel, hogy feleslegessé válik az ember. A probléma gyökere abban rejlik, hogy olyan mértékü és léptékü változások előtt áll a társadalmunk a mesterséges intelligenciának köszönhetően, amire nincs felkészülve. Vernor Vinge technológiai szingularitás elmélete szerint a mesterséges intelligenciák hatványozottan képesek javítani önmaguk elméjét az emberi intelligenciához képest, s így a technológia fejlödése olyan mértékben 
változtatja meg a környezetünket, amihez már nem leszünk képesek majd alkalmazkodni. Ezzel ellentétben Raymond Kurzweil a Google fejlesztési igazgatójának elmélete szerint a szingularitás folyamatosan a teljes emberiség részvételével fog végbe menni. Ugyanakkor a gondolkodó gépek kifejlesztése a puszta létünkre is veszélyt jelent (Z. Karvalics, 2015).

Az Ipar 4.0 egyik jelentős különbsége az előző fázisokhoz képest a fejlődés exponenciális jellege, mely „felforgató” hatással van a termelésre, a kormányzásra, a fogyasztásra, életünk mindennapjaira. Kérdéses, hogy a technológia fejlődéséből következö termelés hatékonyságának növekedéséből fakadó nyereségtöbblet hogyan kerül majd elosztásra az egyes társadalmi rétegek között (Bayer, 2020).

A digitális forradalom szintén jelentős eredménye a földrajzi korlátok „lebontása”, melyben elvitathatatlan szerepe van az Internet korlátlanságának és korlátozhatatlanságának, hiszen az információhoz való korlátlan hozzáférés újabb és újabb dimenziókat tár fel. A digitális média segítségével azonban soha nem látott sebességgel terjedhetnek el valótlan információk is, illetve egyre nagyobb tere van az érdekek mentén történő tisztességtelen befolyásolásnak az adatbiztonság csorbulásával (HTTP3). Ezen a ponton viszont ismételten egy sarkalatos kockázathoz érkezünk, amikor már a jogi keretek sem nyújtanak biztonságot. De ez már egy másik közlemény témája lehetne.

\section{Következtetések, kitekintés}

Összefoglalásként elmondható, hogy minden jelentős technológiai haladáshoz szükség volt átmeneti időszakra, amikor a társadalomnak alaposabban meg kellett ismernie a technológiát és be kellett azt építenie a mindennapi életébe. Tehát a mesterséges intelligencia világában is szükséges az érdekelt felek együttmüködése, a támogató feltételek kialakítása, továbbá az inkluzív tervezés és kialakítás a hozzáférhetőség alapja. Mivel az Internet tulajdonképpen „közmü” rangot élvez, ezért az elmúlt időszakot jellemző korlátozott fizikai kontaktust engedélyező élethelyzet kapcsán sokat fejlődhetett a digitalizáció, újabb lehetőségek nyíltak mind ipari, mind pedig társadalmi vonatkozásban és a tapasztalatok is vonzóvá tették az „új világ” felé fordulást.

A feldolgozott irodalmak mondanivalói ráirányították arra a figyelmet, hogy a munka világa mennyire nyitott a müszaki, gazdasági, társadalmi innováció(k)ra. A Holt költők társasága c. amerikai film (rendező Peter Weir) egy részletének (HTTP7) gondolatisága, nevezetesen a különböző nézetek ideológiája, a más szemszögből történő szemlélés esszenciális erővel bír az innováció kimunkálásában.

Tény az is, hogy sok esetben úgy tüntetjük fel a mesterséges intelligencia adaptálása kapcsán a generációk közötti különbségeket, mint egy olyan szakadékot, amit nem lehet áthidalni. Holott szó sincs erről, csupán közös pontokat kell keresnünk, mert a generációk együtt jobban teljesítenek, mint külön-külön, ami arra enged következtetni, hogy a „munka világában” minden generációnak helye van.

Megállapítható továbbá, hogy az adatbiztonság, mely kiterjed a hiteles információforrásra is és az adatarchiválás biztonságára is, kulcsmotívum az új digitális világrendben, hiszen minél fejlettebb egy társadalom technikai 
infrastruktúrája, annál érzékenyebb a manipulálásra és az infokommunikációs rombolással szemben. Ugyan nem a munka világának témaköréhez illeszkedik, de szintén kétségeket ébreszt a mesterséges intelligenciával kapcsolatban a digitális harcviselés, nevezetesen a hadviselés robotizálásának trendje, tehát fontos a békés célú felhasználás.

A robotok autonómiája vonatkozásában az alkalmazásuk során esetlegesen felmerülő komoly etikai, pszichológiai és jogi aggályokkal eddig uniós szinten nem foglalkoztak (megfelelően). Különösen árnyalt a viszony a felelősség és a létrejövő új gazdasági kapcsolat és munkaviszonyok tekintetében, mivel az autonómia teljes mértékben csak emberi tulajdonságként tartható számon. Tehát a mesterséges intelligencia alkalmazásához szilárd jogi és etikai keretekre van szükség (COM(2020)64). Ha kiindulási pontként tekintjük, hogy saját magunktól ne vegyük el az élmények örömét, akkor kardinális kérdés az emberiség szempontjából, sikerüle a vezető hatalmaknak a mesterséges intelligencia fejlesztése terén minden szereplő számára elfogadható normákat megalkotni és egységes keretrendszerben megállapodni. Ugyanis minden reménységünk megvan „új típusú” oktatási rendszerek, iskolák, munkahelyek, munkakörülmények kialakulására és rendszerben gondolkodni.

\section{Irodalomjegyzék}

Andor L. (2018): A digitalizáció és munka világa. Mi várható a robotforradalom után? Magyar Tudomány, 179 (1): 47-54. https://doi.org/10.1556/2065.179.2018.1.5

Bagdy E. (1991): A hivatásra nevelés. Iskolakultúra, 1 (7-8): 93-97. $<$ http://www.iskolakultura.hu/index.php/iskolakultura/article/view/28376> (2020.12.06.)

Bayer J. (2020): A „második gépkorszak” társadalmi kihívásai. Szabad Piac, (1): 20-37.

Brynteson, R. (2012): Innovation at work (55 Activities to Spark Your Team's Creativity). AMACOM, New York.

Fine, D., Havas A., Hieronimus, S., Jánoskuti L., Kadocsa A., Puskás P. (2018): Átalakuló munkahelyek: az automatizálás hatása Magyarországon. McKinsey \& Company, Budapest.

Erdész V. (2020): A mesterséges intelligencia fogalma, jelentősége és hatásai a védelmi szektorra. Felderitö Szemle, 19 (1): 118-132.

Kelemen M. (szerk.) (2018): A munka átalakulása, a digitalizáció és a robotizáció lehetséges következményei (munkaanyag). Szakszervezeti háttéranyag a Nemzeti Gazdasági és Társadalmi Tanács 2018. október 12-i ülésére, Budapest.

Lai, K. W., Khaddage, F., Knezek, G. (2013): Blending student technology experiences in formal and informal learning. Journal of Computer Assisted Learning, 29 (5): 414-425.

Makó Cs., Illésy M., Borbély A. (2018): Automatizáció és kreativitás a munkavégzésben. Educatio, 27 (2): 192-207. < http://real.mtak.hu/94281/> (2020.10.02.)

Maróti A. (2014): Merre tovább andragógia? - A fogalomváltások tanulságairól. Opus et Educatio, 1 (1): 4-10.

Négyesi I. (2019): A mesterséges intelligencia és a hadseregek. Hadtudomány, 29 (3): 71-79. https:doi.org/10.17047/HADTUD.2019.29.3.71

Stacey, N., Ellwood, P., Bradbrook, S., Reynolds, J., Ravetz, J., Williams, H., Lye, D. (2018): Foresight on new and emerging occupational safety and health risks associated with digitalisation by 2025. (European Risk Observatory - Summary) European Agency for Safety and Health at Work, Bilbao.

Pickering, C., Byrne, J. (2014): The benefits of publishing systematic quantitative literature reviews for $\mathrm{PhD}$ candidates and other early-career researchers. Higher Education Research \& Development, 33 (3): 534-548. 
Ropolyi L. (2020): Az intelligencia három változata. Szabad Piac (A bizonytalanság kora), (2): 138145

Suchodolski, B. (1964): A jövőnek nevelünk. Tankönyvkiadó, Budapest. 540 p.

Tóthné P. L. (2020): Digitális intelligencia - készségek a sikeres digitális élethez. In: A kultúraváltás hatása az egyéni kompetenciákra: a digitális kompetencia modelljei. Eszterházy Károly Egyetem Líceum Kiadó, Eger. 106-118. https://doi.org/10.46403/Akulturavaltashatasaegyeni.2020.106

Vasali Z. (2020): A zöld forradalom digitalizációs reform nélkül kivitelezhetetlen. Szabad Piac, (1): $113-123$.

Z. Karvalics L. (2015): Mesterséges intelligencia - a diskurzusok újratervezésének kora. Információs Társadalom, 15 (4): 7-41.

FEHÉR KÖNYV - Fehér könyv a mesterséges intelligenciáról: a kiválóság és a bizalom európai megközelítése. Európai Bizottság, $\operatorname{COM}(2020) 65$ Brüsszel, 2020. $02 . \quad 19$. $<$ https://ec.europa.eu/info/sites/info/files/commission-white-paper-artificial-intelligencefeb2020_hu.pdf $>$ (2020.11.22.)

Jelentés a mésterséges intelligencia, a dolgok internete és a robotika biztonsági és felelősségi vonatkozásairól. Európai Bizottság, $\operatorname{COM}(2020) 64$ Brüsszel, 2020. $02 . \quad 19$. $<$ https://www.europarl.europa.eu/doceo/document/A-8-2019-0019_HU.html > (2020.11.22.)

Magyarország Mesterséges Intelligencia Stratégiája 2020-2030. MIK-DJPP-ITM, Budapest 2020. $<$ https://digitalisjoletprogram.hu/files/6f/3b/6f3b96c7604fd36e436a96a3a01e0b05.pdf> (2020.09.10.)

The Future of Jobs (Report). WEF (World Economic Forum), Cologny/Geneva Switzerland, October $2020<\mathrm{http}: / / \mathrm{www} 3$.weforum.org/docs/WEF_Future_of_Jobs_2020.pdf $>$ (2020.10.22.)

HTTP1: <https://www.mofa.go.jp/files/000486596.pdf> (2020.11.22.)

HTTP2: Mesterséges Intelligencia: A robotok, vagy a főnökök a népszerübbek? <www.muszakimagazin.hu> (2019.10.26.)

HTTP3: < https://willrobotstakemyjob.com/> (2020.12.22.)

HTTP4: <https://magyarmezogazdasag.hu/2019/07/23/gyors-hatekony-talajelemzes-munkavegzeskozben> (2020.12.22.)

HTTP5: Excellence and trust in artificial intelligence. European Commission, Brussel 2020 (20 February) < <https://ec.europa.eu/info/strategy/priorities-2019-2024/europe-fit-digitalage/excellence-trust-artificial-intelligence_en> (2020.09.01.)

HTTP6: Jönnek a robotok: fájni fog az átállás. <www.piacesprofit.hu> (2018.10.01.)

HTTP7: Holt költők társasága (1989) részlet - Különböző nézetek, más szemszög $<$ https://www.youtube.com/watch?v=jlWV3hVH_78\&t=32s> (2020.12.06.) 